\section{The Reaction of}

\section{Hexafluoroisopropylideniminolithium with}

Fluorophosphoranes: The Synthesis of

Hexafluoroisopropylideniminofluorophosphoranes

and Fluorophosphine-bis(Trifluoromethyl)-

Hexafluoroisopropylideniminomethyl-imides

\author{
James AndRew Gibson \\ and ReINHARD Schmutzler
}

Lehrstuhl B für Anorganische Chemie der Technischen Universität Braunschweig

(Z. Naturforsch. 29b, 441-442 [1974]; received February 13, 1974)

Synthesis, Fluorophosphoranes,

Fluorophosphine-imides, NMR exchange

The use of the lithium salt of hexafluoroisopropylidenimine in substitution reactions with compounds containing active halogens is well known ${ }^{1-4}$. The structure of the products is interesting due to the possibility of the nitrogen atom being $\mathrm{sp}^{2}$ hybridized (angular) (A) or sp-hybridized (linear, with the lone pair involved in bonding to the central metal atom), (B) 4 .<smiles></smiles>
or

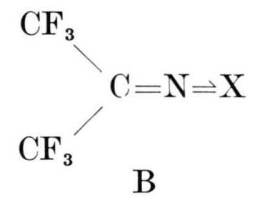

Structure A imparts magnetic non-equivalence to the $\mathrm{CF}_{3}$ groups; "inversions" at nitrogen have been studied in a number of cases by variable temperature ${ }^{19} \mathrm{~F}$ NMR spectroscopy ${ }^{1,5-8}$.

Because of the continued interest ${ }^{9-12}$ in ligand exchange processes in organophosphorus compounds, particularly fluorophosphoranes and phosphorus nitrogen systems, it was decided to undertake a study of the synthesis of fluorophosphoranes containing the electronegative hexafluoroisopropylidenimino group. Our preliminary results are reported here.

Reactions were carried out in pentane solvent using solutions of hexafluoroisopropylideniminolithium prepared by the reaction of butyl lithium with the free imine ${ }^{1}$. Hexafluoroisopropylidenimine was prepared from hexafluoroacetone ${ }^{13}$. The fluorophosphoranes were condensed onto the lithium salt at $-196{ }^{\circ} \mathrm{C}$ and allowed to warm slowly to room temperature. Reaction occurred over periods of 2 hours $-1 \frac{1}{2}$ days; lithium fluoride was separated by filtration and the products were separated by vacuum distillation and/or on the vacuum line. The products were identified by IR, mass spectrometry, elemental analysis and ${ }^{19} \mathrm{~F},{ }^{1} \mathrm{H}$ and ${ }^{31} \mathrm{P}$ NMR spectroscopy. Despite the use of 1:1 stoichiometry unreacted fluorophosphorane was always found and the reactions appeared to follow a scheme outlined below.

Where $\mathrm{R}=\mathrm{C}_{2} \mathrm{H}_{5}$, compound $\mathbf{1}$ was produced in approximately $25 \%$ yield (based on $\mathrm{RPF}_{4}$ starting material) while compound $\mathbf{2}$ was produced in

$$
\mathrm{RPF}_{4}+\mathrm{Li}^{+(-)} \mathrm{N}=\mathrm{C}\left(\mathrm{CF}_{3}\right)_{2} \rightarrow \mathrm{RP}\left(\mathrm{F}_{3}\right)-\mathrm{N}=\mathrm{C}\left(\mathrm{CF}_{3}\right)_{2}+\mathrm{RP}\left(\mathrm{F}_{2}\right)=\underset{\mathbf{N}-\mathrm{C}_{-} \mathrm{N}=\mathrm{CF}_{\mathbf{2}}^{\mathrm{CF}_{3}}}{\mathrm{CF}_{3}} \mathrm{CF}_{3}
$$

$$
\left(\mathrm{R}=\mathrm{C}_{2} \mathrm{H}_{5}, \mathrm{C}_{6} \mathrm{H}_{5}\right)
$$

approximately $30 \%$ yield. Where $\mathrm{R}=\mathrm{C}_{6} \mathrm{H}_{5}$, compound 1 was not present in significant amounts but 2 was formed in approx. $40 \%$ yield.

A number of other $\mathrm{CF}_{3}$-containing products were also formed but positive identification was not possible because the yields were very low. Compound $\mathbf{2}$ is analogous to products obtained by
Shreeve and co-workers ${ }^{1,3,8}$ from the reaction of $\mathrm{COX}_{2}$ and $\operatorname{SOX}_{2}(\mathrm{X}=\mathrm{Cl}, \mathrm{F})$ and $\mathrm{SF}_{4}$ with hexafluoroisopropylideniminolithium. The formation of such compounds may occur by a halide migration mechanism ${ }^{1,3}$ or, in the case of the compounds reported here, may be due to further attack on the isopropyl carbon by hexafluoroisopropylideniminolithium.

Requests for reprints should be sent to Dr. JAMES Andrew Gibson, Lehrstuhl B für Anorganische Chemie der Technischen Universität, D-3300 Braunschweig, Pockelsstraße 4.

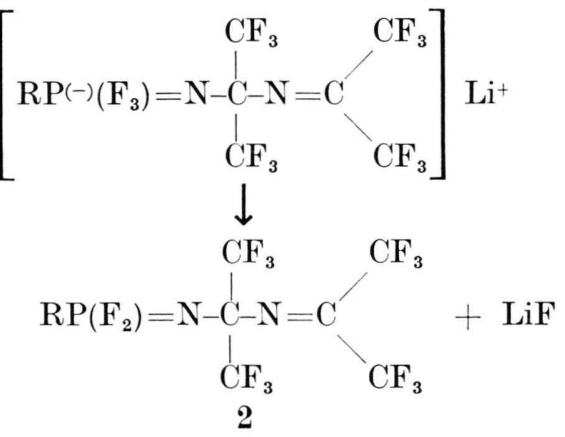


The generality of the synthetic procedure to give hexafluoroisopropylideniminofluorophosphoranes

(1) and fluorophosphine-bis(trifluoromethyl)hexafluoroisopropylideniminomethyl-imides (2), is presently under investigation. Compound 1 undergoes intramolecular exchange and coalescence of equatorial and axial fluorine NMR resonances occurs at, or just above, room temperature. Compound $\mathbf{2}$ also exhibits a temperature dependent ${ }^{19} \mathrm{~F}$ NMR spectrum. Two separate resonances are assignable to the terminal $\mathrm{CF}_{3}$ groups at low temperatures but

${ }^{1}$ R. F. Swindell, D. P. BabB, T. J. Ouellette, and J. M. Shreeve, Inorg. Chem. 11, 242 [1972].

2 S. G. Metcalf and J. M. Shreeve, Inorg. Chem. 11, 1631 [1972].

3 R. F. Swindell and J. M. Shreeve, J. Amer. chem. Soc. 94, 5713 [1972].

${ }^{4}$ M. F. Lappert and D. E. Palmer, J. C. S. Dalton 1973, 157.

5 P. H. Ogden and R. A. Mitsch, J. Amer. chem. Soc. 89, 5007 [1967].

${ }_{6}$ P. H. Ogden, J. org. Chemistry 33, 2518 [1968].

${ }^{7}$ G. E. Hall, W. J. Middleton and J. D. Roberts, J. Amer. chem. Soc. 93, 4778 [1971]. broadening occurs as the temperature is raised. A full study of the temperature dependence of the ${ }^{19} \mathrm{~F}$ NMR spectra of compounds $\mathbf{1}$ and $\mathbf{2}$ is presently in progress.

The financial support of N.A.T.O. through a Postdoctoral Fellowship (to J. A. G.) is gratefully acknowledged; thanks are also due to Verband der Chemischen Industrie, Frankfurt am Main, and to Dr. D. E. Young, Allied Chemical Corporation, Morristown, N.J., USA for a gift of hexafluoroacetone.

8 R. S. Swindell and J. M. Shreeve, Inorg. Nucl. Chem. Letters. 8, 759 [1972].

9 P. Gillespie, P. Hoffman, H. Kluscek, D. Marquarrding, S. Pfohl, F. Ramirez, E. A. Tsolis, and I. UGI, Angew. Chem. Int. Ed. 10, 687 [1971].

10 R. Schmutzler, Angew. Chem. Int. Ed. 4, 496 [1965].

11 G. M. Whitesides and H. G. Mitchell, J. Amer. chem. Soc. 91, 5384 [1969].

12 A. H. Cowley and J. R. Schweiger, J. C. S. Chem. Commun. 1972, 560.

13 W. J. Middleton and C. G. Krespan, J. org. Chemistry 30, 1398 [1965].
Reaktionen in elektrischen Entladungen, I.

\section{Ein neues Verfahren zur kontinuierlichen Synthese von Diacetylen}

Reactions in Electrical Discharges, I.

A New Method for the Continuous Preparation of Diacetylene

R. Grziwa, G. Rosskamp und R. N. Schindler Institut für Physikalische Chemie der Kernforschungsanlage Jülich GmbH

(Z. Naturforsch. 29 b. 442-444 [1974]; eingegangen am 14. Januar 1974)

Electrical discharges, Diacetylene synthesis

Für die Synthese von Diacetylen sind in der Literatur eine Reihe von Verfahren angegeben ${ }^{1}$. Allen diesen Verfahren ist gemeinsam, daß sie über mehrere Stufen verlaufen bzw. daß die Ausbeuten unbefriedigend sind. Im Rahmen einer Untersuchung über die Anwendbarkeit plasmachemischer Verfahren zur Synthese organischer Verbindungen wurde eine einfache kontinuierliche Methode zur direkten Synthese von Diacetylen aus Acetylen gefunden, die im folgenden beschrieben werden soll.

Sonderdruckanforderungen an Prof. Dr. R. N. Schindler, KFA, Institut für Physikalische Chemie, D-51\%0 Jülich 1, Postfach 365 .

\section{Experimenteller Teil}

Die Untersuchungen wurden in einem konventionellen Strömungssystem ausgeführt. Technisches Acetylen, das einer Stahlbombe entnommen wurde, passierte zu seiner Reinigung vor dem Eintritt in die Plasmazone mehrere mit Trockeneis gekühlte Fallen. Mit Hilfe einer Pumpkombination Leybold EZ5-D6 wurden bei Drücken zwischen 0,5 und 5 Torr lineare Strömungsgeschwindigkeiten von 10 bis $50 \mathrm{~m} / \mathrm{sec}$ erreicht. Bei einem Durchmesser des Strömungsrohres von ca. $20 \mathrm{~mm}$ ergaben sich somit Aufenthaltsdauern von $<10^{-3} \mathrm{sec}$ in der Mikrowellenantenne. Der Acetylendurchsatz betrug mehrere Gramm pro Minute.

Die Erzeugung des Plasmas erfolgte mit einem kommerziellen $2450 \mathrm{MHz}$-Sender, maximale Leistung 200 Watt, unter Verwendung eines Evenson. Resonators, Typ $4^{2}$. Der Sender wurde durch Ankopplung an einen Pulsgenerator (Solatron) diskontinuierlich betrieben. Bei Rechteckpulsen von $10 \mu \mathrm{sec}$ Dauer und einer Wiederholfrequenz von $10^{4} \mathrm{sec}^{-1}$ wurde die Substanz im Schnitt während ihres Aufenthaltes im Mikrowellenresonator etwa 10mal dem Ladungsgeschehen ausgesetzt. Das Tastverhältnis für die Pulsung wurde oszillographisch überwacht. Die Optimierung der Anpassung erfolgte mit Hilfe von Teflonschiebern.

Ein aliquoter Teil der Produkte wurde kontinuierlich dem Strömungssystem entnommen und nach Komprimierung mit einer Töpplerpumpe gaschro- 